\title{
The silent treatment: Alejandra Basualto's a esthetic of censorship
}

\section{El manejo del silencio: La estética de la censura en Alejandira Basualto}

\author{
Resha Cardone ${ }^{1}$ \\ Southern Connecticut State University
}

\section{ABSTRACT}

Alejandra Basualto is a little studied yet significant Chilean prose writer and poet whose first short story collection, La mujer de yeso (1988), exemplifies the redefinition of the woman writer that occurred in many femaleauthored fiction texts published during the Pinochet regime. Exemplifying the aesthetic of censorship and silence characterizing her entire short story collection, analyses in this article of "La espera" and "1954" reveal how Basualto undermines the repressive hierarchies defining Chilean politics of the dictatorship era as well as the national literary establishment through what I call her aesthetic of silence and censorship. The art of censorship recalls the context of dictatorial repression Basualto confronts in this

1 Dirección electrónica: cardoner1@southernct. edu Teléfono: (802) 522-6768 (EE.UU.) Institución: Southern Connecticut State University Ubicación: New Haven, Connecticut, Estados Unidos https://orcid.org/0000-00022198-1114) collection, while the aesthetic of silence points to the dialogue with international feminist thought perceptible in the compilation. In these two short stories, creative women protagonists challenge institutional power structures by assuming the feminized positions of vulnerability and silence. Basualto incorporates literary strategies like metaphors, mythical allusions, and ellipses to create an intricate textual dynamic representing repressive military tactics like censorship and disappearing dissidents. A story inscribed on a tortured and repressed female body longing to create, an extended metaphor for the Chilean nation and its writers, "La espera" showcases artists' frustrated attempts to create during the regime while representing the psychological despair of Chileans suffering due to the "disappearance" of their loved ones. The focus on women and writing in "1954" depicts women authors' need to identify female literary models and to imagine belonging to same-sex writers' communities to succeed as authors despite the 
male-dominant literary establishment, traditional gender roles, and military and self-censorship.

\section{KEYWORDS}

80s Generation, Chilean Literature of the Dictatorship, Censorship of Latin American Literature

\section{RESUMO}

Alejandra Basualto é uma significativa escritora de prosa e poesia chilena pouco estudada, cuja primeira coleção de contos, La mujer de yeso (1988), constitui um exemplo da redefinição das escritoras mulheres que se produz em muitos dos textos de ficção de autoria feminina publicados durante o regime de Pinochet. Exemplificando a estética da censura e o silêncio que caracteriza toda sua coleção de contos, as análises neste artigo de "La espera" e "1954" revelam como Basualto enfraquece herarquias repressivas que definem a política chilena da era da ditadura, assim como o estabelecimento literário nacional através do que eu denomino como a estética de silêncio e censura. A arte da censura evoca o contexto de repressão ditatorial que Basualto enfrenta nesta coleção, enquanto a estética do silêncio aponta para o diálogo com o pensamento feminista internacional perceptível na compilação. Nessas duas histórias, as mulheres criativas protagonistas desafiam as estruturas de poder institucional assumindo posições feminizadas de vulnerabilidade e silêncio. Basualto incorpora estratégias literárias como metáforas, alusões míticas e elipses para criar uma intrincada dinâmica textual que representa táticas militares repressivas como a censura e a ação de desaparecer dissidentes. Uma história inscrita num corpo feminino torturado e reprimido que anseia criar, uma metáfora extendida da nação chilena e seus escritores, "La espera" revela as tentativas frustradas dos artistas por criar durante o regime, enquanto representam o desespero psicológico dos chilenos que sofrem devido ao "Desaparecimento" de seus seres queridos. O foco nas mulheres e na escrita em "1954" descreve a necessidade das autoras de identificar modelos literários femininos e imaginar pertencer à comunidades de escritoras do mesmo sexo para ter sucesso como autoras apesar do estabelecimento literário dominado pelos homens, os papéis de gênero tradicionais, assim como também o militar e a autocensura.

\section{RESUMEN}

Alejandra Basualto es una significativa prosista y poeta chilena poco estudiada, cuya primera colección de cuentos, La mujer de yeso (1988), ejemplifica la redefinición de las escritoras mujeres que se produce en muchos de los textos de ficción de autoría femenina publicados durante el régimen de Pinochet. Ejemplificando la estética de la censura y el silencio que caracteriza a toda su colección de cuentos, los análisis en este artículo de "La espera" y "1954" revelan cómo Basualto socava las jerarquías represivas que definen la política chilena de la era de la dictadura, así como el establecimiento literario nacional a través de lo que yo llamo la estética de silencio y censura. El arte de la censura recuerda el contexto de represión dictatorial que Basualto enfrenta en esta colección, mientras que la estética del silencio apunta al diálogo con el pensamiento feminista internacional perceptible en la compilación. En estos dos relatos, las mujeres creativas protagonistas desafían las estructuras de poder institucional asumiendo posiciones feminizadas de vulnerabilidad y silencio. Basualto incorpora estrategias literarias como metáforas, alusiones míticas y elipses para crear una intrincada dinámica textual que representa tácticas militares represivas como la censura y el acto de desaparecer a los disidentes. Una historia inscrita en un cuerpo femenino torturado $y$ reprimido que anhela crear, una metáfora extendida de la nación chilena y sus escritores, 
«La espera» muestra los intentos frustrados de los artistas por crear durante el régimen mientras representan la desesperación psicológica de los chilenos que sufren debido a la «Desaparición» de sus seres queridos. El enfoque en las mujeres y la escritura en "1954" describe la necesidad de las autoras de identificar modelos literarios femeninos e imaginar pertenecer a comunidades de escritoras del mismo sexo para tener éxito como autoras a pesar del establecimiento literario dominado por hombres, los roles de género tradicionales, así como también el militar y la autocensura.

PALABRAS CLAVE: Generación de los 80, literatura chilena de la dictadura, censura de la literatura latinoamericana.

\section{INTRODUCTION}

In 1986 Chilean intellectual, Sergio Pesutic, founded the Prensa Oxímoro for the sole purpose of publishing the press's only title, La inteligencia militar. Scoffing at military censorship during Pinochet's regime (1973-1989), the publication is an inordinately thicme of hundreds of blank pages. As is well known, promptly after the 1973 coup d'état, the military declared a culture war known as the Cultural Blackout (Apagón cultural): it murdered, tortured, incarcerated, and exiled the dissidents, instituted a curfew, censored all forms of expression, and prohibited gatherings where ideas could be exchanged. Despite the Cultural Blackout, a clandestine literary field emerged, and artists and intellectuals like Pesutic used cultural production to protest against the regime. Censorship laws were ambiguous and uneven during the dictatorship; the government, for instance, declared freedom of speech and the press while regulating the media and cultural production at will. ${ }^{2}$

$2 \quad$ Constable and Valenzuela describe the lack of clarity of censorship laws during the regime, explaining that the military simultaneously declared freedom of the press while censoring each form of expression in Chile. They also note that the military implemented edicts unevenly, depending on myriad political factors. See their chapter entitled "The Culture of Fear."
Despite the censorship the junta unwittingly produced a dynamic underground art scene known variously as the Generation of 1980, the Nueva escena, the Avanzada, the Postcoup Generation, and the Generation NN. This movement was characterized by an intricate formal experimentation with language and visual media that sought to erode the authoritarian features inherent in art, society, and politics. Military and self-censorship created a generation of literary innovators, as artists concealed messages in wordplays, double meanings, metaphors, ellipses, as well as mythological and literary allusions (Espinosa 66; Millares and Madrid 116; Osses 144; Zurita 7).

Just as censorship unwittingly produced an active literary underground, the military's imposition of traditional gender roles unintentionally intensified feminist activity and produced the largest boom of women writers in Chilean history. Many of these authors, such as Pía Barros, Diamela Eltit, Heddy Navarro, and Ana María del Río, among others, wrote erotic literature in which women's bodies-silenced, tortured, and sexualized-represented both the nation under siege and repression within a wide range of human institutions, particularly gender relationships. ${ }^{3}$ Women's narratives of the era often depict female characters' processes of becoming writers, recalling the military's attempt to control cultural production as well as its interest in halting the women's liberation movement.

\section{ANALYSIS: ALEJANDRA BASUALTO'S AESTHETIC OF SILENCE AND CENSORSHIP}

Alejandra Basualto's (b. 1944) first short story collection, La mujer de yeso (1988), exemplifies the redefinition of the woman writer occurring in fiction texts published during the regime.

$3 \quad$ In his article "De piel a piel: El erotismo como escritura en la nueva narrative femenina de Chile," Juan Armando Epple analyzes erotic writing produced by Chilean women after the 1973 coup. 
Basualto is a significant poet and prose writer, ${ }^{4}$ yet few scholars have explored her work $^{5}$ Exemplifying the aesthetic of censorship and silence characterizing the entire collection, analyses in this article of the short stories "La espera" and "1954" reveal how Basualto undermines the repressive hierarchies defining Chilean politics of the dictatorship era as well as the national literary establishment through what I call her aesthetic of silence and censorship. The art of censorship recalls the context of dictatorial repression Basualto confronts in this collection, while the aesthetic of silence points to the dialogue with international feminist thought perceptible in the compilation. In these two short stories, creative women protagonists challenge institutional power structures by assuming the feminized positions of vulnerability and silence. Basualto incorporates literary strategies like metaphors, mythical allusions, and ellipses to create an intricate textual dynamic representing repressive military tactics like censorship and disappearing dissidents. A story inscribed on a tortured and repressed female body longing to create, an extended metaphor for the Chilean nation and its writers, "La espera" showcases artists' frustrated attempts to create during the regime while representing the psychological despair of Chileans suffering due to the "disappearance" of their loved ones. The focus on women and writing in "1954" depicts women authors' need to identify female literary models and to imagine belonging to same-sex writers' communities to succeed as authors despite the male-dominant literary establishment, traditional

\footnotetext{
$4 \quad$ Basualto has published six books of poetry, three short story collections, and a novel. Her work has been translated into five languages and has appeared in numerous anthologies throughout the Americas and in Europe. She directs poetry workshops and is the editor of La Trastienda.

$5 \quad$ Several articles exploring Basualto's poetry and prose have been published, including Ana María Cuneo's examination of Basualto's poetry and Carmen Tisnado's study of lesbianism in Basualto's short story, "Mujeres grandes," from her collection, Territorio exclusivo (1991). My dissertation chapter on Basualto's La mujer de yeso, from which this article is extracted, is the analysis of her dictatorship-era prose work.
}

gender roles, and in the case of Basualto, military and self-censorship.

Every story in La mujer de yeso brings to bear wordlessness and absences. Basualto creates moods and sensations through lyrical prose, and the narrations include almost no dialogue. The characters are either silenced or choose silence as a response; they are dead and they die alone; they speak only rarely and, when they do, they tend to be misunderstood. Numerous characters feel they are continually being watched and monitored while others have separated from loved ones and long to rekindle lost relationships. There are characters who have vanished mysteriously, and their loved ones are terrified to ask questions about their whereabouts. The pervasive sense of death, sudden disappearance, depression, aloneness, violence, and the inability or unwillingness to speak suggest the regime, but Basualto only hints that the stories may take place in Pinochet's Chile.

Chilean academician, Eugenia Brito, has noted artists' predilection to comment on the Pinochet regime indirectly through constant deferrals and displacements. Through what she terms the "arte de disimulo," a performative mode of communication expressed through dissimulation, Brito argues that Chilean artists fashioned an alternative system of communication in which they "spoke" by means of physical gestures and signals rather than through speech acts (17). La mujer de yeso exemplifies this art of dissimulation: the collection includes strategic silences and absences that urge readers to consider each critically. Replicating common literary strategies of this period, La mujer de yeso transforms self-censorship into a tactic. The author urges interpretations of missing information and characters by including many stories whose theme and style demonstrates that silence can be an effective mode of expression. 
The reversal of socially and politically imposed silences in Latin American women's writing has been a topic of substantial interest among feminist literary critics. In "Tretas del débil," Josefina Ludmer explores the way the Mexican author Sor Juana Inés de la Cruz tricked the Church and State through a tactical appropriation of feminine wordlessness that she used in her writing to break a silence she ostensibly embraced, thereby eroding the logic of patriarchal dominance. Similarly, Debra A. Castillo has outlined in her book, Talking Back: Toward a Latin American Feminist Criticism, the way women writers of the region have exploited sexist mores to further gender liberation. Castillo departs from the premise that women are positioned as silent, distant, and untouchable others, illustrating how several celebrated Latin American women writers have transformed gender roles by appearing to ascribe to them:

Under old traditional codes, the woman [. . .] remained silent and withdrawn. In the counterhegemonic response to this official silencing, she executes a dizzying dance of negativity, appropriating silence as a tactic neither for saying nor for unsaying but for concealing a coded speech between the lines of the said and the unsaid. (41)

For her part, Doris Sommer has also urged readers of Latin American women writers to learn to "hear creative refusals to talk" because "[s]ilence is not simply a prison in [an] asymmetrical world;" rather, "[s]ometimes it is a tactic" (21). Sommer contends that wordlessness can actually constitute "flamboyant noncompliance" (126), while Castillo argues for the power of silence: "[t]he revolutionary response to silencing is its resemanticization: to use silence as a weapon [. . . ] or to break silence with hypocrisy" (38-9). The strategic use of silence as a tactic undermining the regime and the patriarchy is precisely what Basualto does in La mujer de yeso.

\section{THE REPRESSED FEMALE BODY AS NATIONAL ALLEGORY IN "LA ESPERA"}

"La espera" tells the story of a pregnant woman who lives alone in the countryside of an unidentified nation. The nameless protagonist is unable to give birth for a number of years while she waits for the return of her husband who has disappeared while on an uncertain assignment to an indeterminate southern border. While the pregnant woman awaits the homecoming of her husband, she is incapable of delivering that which is most natural to her (the baby) in the same way that Chileans could not share ideas or produce art openly during the years of military rule. During the passage of time, she attempts to express herself in other ways, yet, paralleling her inability to birth her child, her other projects fail, broadening the metaphorical significance of the text. The denouement leaves the fate of the family in question while the woman slowly decays in the solitude of her home.

The protagonist's failed attempts at rechanneling her primal creativity are central to the action developed within the short story: Basualto presents two key instances that illustrate the woman's futile attempts to reproduce and create, and each example furthers the author's allegorical critique of military and selfcensorship. In one instance, the protagonist tries to satisfy her desire to mother a human child by raising a flock of tiny chicks, nurturing them as if they were human babies. The gentle care she gives the tiny creatures is similar to her devotion to her unborn child. She feeds her infant flock with her best homegrown vegetables, giving them "[. . .] las hojas más tiernas y crujientes de las lechugas de la huerta, los tomates más redonditos y colorados, las papas más nuevas [. . .]" (41). Nonetheless, her attempt to mother the baby chicks ultimately fails, and the chicks slowly die. She finally sells the few survivors. 
As the woman waits for her husband to return so that she can deliver the baby, she fuels her creativity in an alternative way by obsessively knitting baby clothes, beginning with white yarn and finishing only after exhausting every color in the rainbow. Her activity illustrates the woman's urgent need to create-if not a baby, then baby clothes-while the tediousness of her pastime emphasizes the length of her wait:

Pasó varias estaciones tejiendo, hasta que sus dedos palidecieron, y las venas de sus manos se trocaron en enmarañadas líneas de un azul indefinible que se encaramaban por sus brazos hasta el pecho. Pensó después que quizá era niña, y las labores se volvieron rosa, y luego lila y amarillo [. . .], y comenzó a llenar las pequeñas prendas de flores y pájaros y franjas de todos los colores del arco iris. (38-9)

Here the creative process has the same tiring effect on her body as the endless pregnancy: each attempt at reproductionwhether biological or artistic-exhausts her, and ultimately fails.

Extending the metaphor linking the woman's experience to that of Chilean writers during the dictatorship, moths eventually destroy the woman's production of knit goods, recalling the military's attempted eradication of cultural production. There appears to be a power over her, either censorship or self-censorship, that prohibits her from expressing herself:

Pasados cinco años, con todas las habitaciones de la casa llenas de pequeñas cajas que contenían sus primorosas creaciones comenzó a percatarse de que la casa estaba invadida por centenares de polillas que entraban y salían por las ventanas a todas horas del día. [. . .]. Fue abriéndolas una a una para constatar con dolorida expresión que dentro de ellas sólo yacían apelmazados montoncitos de lana de colores. (39)

It is significant that Basualto portrays the woman in the moment of her urgent need to create and chooses to show that mysterious outside forces prohibit her from realizing her creative and procreative endeavors. Embedding a critique of the Cultural Blackout within the woman's story, Basualto invites readers to interpret the woman's experience as that of Chilean artists who were also unable to produce. This reading, moreover, can be extended to Basualto's own frustrations as a writer trying to create during the repressive regime.

The protagonist's propensity to knit as she waits for her husband's return constitutes another strategic device to obscure meaning. In making silence aesthetic, Basualto includes an allusion to the myth of Penelope and Ulysses to advance a critique of military censorship and the detainment and disappearance of dissidents. The choice to make the woman knit while she waits for her husband is strikingly similar to Penelope's weaving of a shroud for Ulysses as she awaited his return from the Trojan War. Like Penelope's continual reweaving of the cloak to delay its completion, moths destroy the knit garments of the protagonist in "La espera." The destruction of each woman's creation as she waits for husband links the two women by way of association. This literary connection highlights the Chilean protagonist's denial that her husband may never return, suggesting he has been "disappeared" during the regime.

The absent husband forms a parallel both with the mythical Ulysses and the thousands of disappeared during the dictatorship, further correlating the two stories. Through a series of loose associations linking the two men, each relying on the reader's familiarity with the myth, Basualto dissimulates her position against the regime and, specifically, its tactic of disappearing. 
Both Ulysses and the husband are involved in a laudable struggle to preserve the integrity of the State. Through this connection Basualto bestows the praiseworthy qualities of Ulysses on the absent husband while linking both the classical character to those Pinochet disappeared, naming them national heroes. Like the archetypal absent hero, Ulysses, and the symbolic loyal wife, Penelope, the couple represented in "La espera" embodies the fragmented Chilean family/nation in a time of war and social upheaval. The literary allusion protects the author because the censors lacked the literary formation to understand the reference, recalling Pesutic's accusation in $\mathrm{La}$ hinteligencia militar.

The ideas of George Bataille can illuminate the protagonist's experience at the subconscious level and provide a deeper understanding of the psychological aspects of the separated Chilean family represented in this story. For Bataille, procreation initiates the death process of the parents: "La muerte y la reproducción se oponen entre sí como la negación y la afirmación" (59). The woman's inability to deliver can thus be explained by Bataille's affirmation that birth and death are interrelated. The protagonist's body will not birth the child because of the final words of the husband to his loyal wife: “. . . él había prometido que regresaría antes del nacimiento y aún faltaba bastante para que fuera revelado de su misión en la frontera sur..." (39). Viewing the tarnished family represented in "La espera" in the context of Pinochet's Chile and in light of Bataille's notion about the connection between death and biological reproduction, the birth of the child would confirm the husband's death, finalizing his demise and revoking his indeterminate status as "disappeared."

6 In Residuos y metáforas, Richard explains the psychological process undergone by Chileans whose family members "disappeared" during the regime. She notes Chileans' "duelo en suspenso," or the marked desire among survivors to continue remembering the disappeared to postpone the finality of their death and not to take part in killing their loved ones by accepting their death (35).
The unknown status of the husband and Chile's disappeared is complicated by the patriarchal and dictatorial language articulated through the television set, a voice presented in contrast with the protagonist's silence. ${ }^{7}$ The "imagen tamizada y eléctrica de la televisión" (39) appears as a smiling General speaks. His address prolongs the uncertainty about the disappeared and, with it, the husband's absence. The General's televised speech, impersonal and technical, is the only voice outwardly expressed in the entire story: "Su voz retumbaba en la solitaria habitación" (39). Though Basualto does not name General Pinochet, the character's reference to the disappeared in his speech, a fragment in the broadcast with which the pregnant woman identifies on a deep personal level, encourages readers to assume he is the dictator: "Él la miraba directamente a los ojos y repetía sin cesar: él volverá, él volverá" (40). The dictator's words confuse the woman and prohibit not only her ability to communicate freely (metaphorically, by birthing the child), but also to consider life beyond the confines of her home. This sense of confusion could be extended to the collective psyche of the Chilean people, many of whom also became psychologically paralyzed by the regime's refusal to confirm the death of the disappeared, which might have enabled some families to heal. The regime's withholding of information and its tactical silence about the disappeared stunted the grief process represented in in the protagonist's unusual inability to give birth in "La espera."

It is also possible to read the baby's delayed delivery as the protagonist's refusal to comply with the regime's imposition of traditional gender roles and conservative family values. The junta gave women a political role as mothers, encouraging them to birth and raise a new 7 Constable and Valenzuela explain the important role of the television to the regime, arguing that, "[it] was the ideal medium for the authoritarian government: it kept people home, created a direct link between the individual and the state, filtered reality through an appealing prism, and encouraged consumption instead of thought" (155). 
generation of compliant Chileans. ${ }^{8}$ Although the protagonist's motives are unclear, she appears unable to assume the maternal role the General on the screen prescribes for her. Moreover, the author's choice to criticize dictatorial practices through a pregnant woman's story resonates with Latin American women protesters who, like Basualto, exploited the essentialized notion of an alleged sacred motherhood to shield themselves from the military violence against which they protested. Argentina's Mothers of the Plaza de Mayo clearly exemplify this strategic use of motherhood to protest against the disappearance of their loved ones. Basualto's use of a fictional mother to critique the regime implements a similar tactic that uses sanctified motherhood as protection. On the one hand, the protagonist is a quintessential mother figure: she never speaks; her life revolves around family affairs, and she is an archetypal mater dolorosa whose body provides for the expansion of the family and the nation. However, her incredible situation transforms the traditional image of the mother and provides an emotive political interpretation of Chile and its people. The fictional character does not speak, but her troubling situation transforms the traditional image of mother and reveals her body's refusal to function naturally without the appropriate conditions to give birth.

The author does not specify how much time elapses during the woman's pregnancy. However, certain clues such as references to changing seasons, a drought, and frequent mention of days, weeks, months, and years gone by indicate that many years have passed. The constant references to the passage of time permit the reader to infer the woman is pregnant for at least five years. It is possible to conclude as many as fifteen years pass while this woman cannot express herself, thus establishing a temporal allusion to the years under Pinochet before the story's publication in 1988. In the denouement, it is questionable whether the

\footnotetext{
8 See Valenzuela's La mujer in el Chile Militar: to-
} das íbamos a ser reinas (1987). woman will give birth or continue her wait indefinitely, but through an aesthetic of silence and censorship and the woman's story, Basualto communicates a political message against State and gender repression.

\section{IMAGINED COMMUNITIES AND GENEOLOGIES OF CREATION IN “1954”}

Basualto's aesthetic of silence and censorship also manifests in the story "1954." The narration recounts the decisive transformational moment in the life of the protagonist, a young girl with an obvious talent for storytelling who lives in the authoritarian environment of a Catholic boarding school for girls in northern Chile. The first of the story's two parts narrates key aspects of the youngster's life prior to a transformational epiphany that occurs in the narration's second section-the girl's encounter with Chilean Nobel Prize-winning poet, Gabriel Mistral, and her subsequent metaphoric rebirth as a poet and storyteller. In the first part, the girl has been separated from her family because her mother is gravely ill. At school, she does not fit in, and the nuns punish her for her natural proclivities to dream about, imagine, and fabricate stories. The girl is instinctively creative, nonconformist, and is drawn to literature, particularly to poetry and short stories. Although the nuns expose her to canonical literary figures like the Nicaraguan poet, Rubén Darío, they discourage her own development as a writer and chastise her for using language creatively. Nonetheless, she tells stories to her classmates, imagines horrifying and comical fictions about the nuns, and reads voraciously. Further, though she is no more than ten years old, she has developed literary taste: she finds the rosary repetitive and unimaginative, but loves litanies for their poetic cadence. The nuns' and her schoolmates' disapproval of the girl forces her to retreat further into the fictional world, her only escape from the miserable conditions she encounters at school and at home. The girl has no contact 
with her mother, who is confined to a bedroom she cannot enter when she visits home. She remembers the parent tenderly as the person who sparked her interest in literature by reading to her nightly before the illness. The girl comforts herself by reading and spending her weekends roaming about the arid desert wasteland alone. At the end, the protagonist invents an alternative reality, adopting Mistral as a stand-in maternal figure during the poet's brief visit to her school.

Recalling the heartrending biography of Mistral, who endured the tragic suicides of her lover and nephew and who lamented in her verse an unrealized desire to become a mother, Basualto characterizes the protagonist as a misfit artist, forsaken by her loved ones. The only moment in the story when the child feels a sense of belonging is when Mistral delivers her address to the children. The girl is estranged from the other students during the visit and finds herself so distant from Mistral that she cannot even hear her speak, but she feels that she is an integral participant in the event. Basualto obscures the exact identity of the poet by focalizing the third person narration through the young girl, too young to recognize the poet's name. Clearly Mistral, the graying woman is a celebrated national poet and schoolteacher who claims that the children of Chile's northern desert region are her own "niños nortinos" (59). Basualto stresses a profound spiritual and familiar union between the poet and the protagonist: the famous woman identifies and makes sustained eye contact with a special girl in the back row, surely the protagonist, whose need for a literary mentor and maternal surrogate matches Mistral's overwhelming and unmet desire to mother a child. There is a silent, almost supernatural union between Mistral, the writer/ mother, and her young protégée. The exchange consists of nothing more than a look, yet this contact produces a brilliant light enveloping the poet and her "child" as they observe each other, suggesting the magical experience will transform the girl into an artist. In that moment the protagonist becomes a part of an imagined group of women writers who, unbeknownst to the fictive literary mother, Mistral, will induce the budding author to transform her undeveloped storytelling ability into written texts. Supporting this prediction, Basualto includes several notable autobiographical clues that suggest that the story "1954" and the collection La mujer de yeso incarnate the child's realization of her literary aspirations in her adult life. For instance, the author herself ended up cultivating poetry and prose while, as a child in the 1950s, she also attended a religious boarding school in the northern desert city of La Serena near Mistral's homeland, El Valle del Elqui. ${ }^{9}$

Although the story is set several decades before the military coup, Basualto's narration nevertheless obliquely confronts the regime's attempt to sever ties between artists and intellectuals and to counter the women's liberation movement of the 1970s and 1980s. The repressive ambiance of violent discipline in which the young girl lives at the parochial school recalls the regime, yet, as with many of the stories in the collection, "1954" appears to have little to do with Chile or the regime. The nuns' authoritarianism is like that of the regime: they use fear tactics to discipline the students; they insist that the girls ascribe to traditional gender roles, and they forbid the protagonist's creative expression.

In one decisive moment, Basualto alludes to the girl's stifled endeavor to write. A considerable portion of the narration recounts an incident in which the nuns punish the child for eating with her left hand. Since she is physically unable to use the other hand, she instead chokes back her tears of humiliation and ceases to eat in the sisters' presence. Later that day the famished girl steals a few unripe coconuts that she secretively eats while the other girls sleep. This episode recreates a repressive milieu and

$9 \quad$ This biographical information was verified during a personal interview with Basualto. 
refers indirectly to the control of writers during the regime. Though it is not expressed in the story, one would assume that the budding author also writes only with her left hand. Through this logical association Basualto invites the reader to imagine a parallel scene where the nuns punish the child for writing with her left hand. This scene is left unwritten, perhaps because it would demonstrate Basualto's discontent with military policy, yet the author's lengthy exposition of the lunchroom episode evokes it nonetheless. It is therefore significant that the girl finds ways in the story to maneuver within the repressive milieu. She chooses to eat in secret rather than conform to the dictates of the nuns, insinuating that, as an adult writer living during the dictatorship, she will not adhere to military edicts either and will satiate her hunger to write clandestinely.

As "1954" figuratively engenders a female Chilean literary lineage composed of the protagonist and Mistral, it intervenes on a dialogue taking place in literary theory and criticism that envisions literary generations metaphorically, through the relationship between fathers and sons and the young and old. Although these seminal theories are modeled on the family, they do not consider female participation; instead, they describe the way that new generations emerge as they break with paternal models. For instance, Herold Bloom argues in his well-known essay, The Anxiety of Influence (1973), that emerging poets distance themselves from their (male) literary precursors. They cleanse themselves of the father's influence and void his powers in order to make space for the new group to emerge as an independent entity. In this cyclical process, when the sons take the place of their symbolic fathers, they expel their antecedents (87-92). In a similar analysis that understands artists' groups visà-vis their position in the literary field, Pierre Bourdieu describes how nascent groups define themselves through differentiation, "reject[ing] what their most consecrated precursors are and do" (240).
Neither Bloom nor Bourdieu explores the distinct intergenerational interaction appearing among generations of women writers who, taking "1954" as one key example, embrace their literary forerunners. Due to women writers' positions as outsiders within the male-dominant literary establishment, it is necessary to observe their self-identification process differently than that of male writers. Within the Chilean context of the 1980s, female authors like Basualto point to a link between the hostile, anti-intellectual posture of the regime and the patriarchal literary establishment to explain emerging women writers' necessity to acknowledge and celebrate their literary origins and to form imaginary bonds with their female literary precursors. Basualto's fiction illustrates that women writers of her time did not want to act alone; they preferred instead to create communities-both imaginary and real-to be able to exist as women writers at a time when patriarchal and military dominance sought to silence women's voices.

Analyzing the dictatorship-era literary scene, Chilean critic Rodrigo Cánovas explores the profound impact of military policy on defining literary generations in the country. His essay demonstrates the way the authors of the Generation of 1980 reacted to the military takeover through their repeated production of fictive accounts illustrating the isolation artists felt from each other and their predecessors, most of whom went into exile after the coup. He notes writers expressed through their activities and their writings a longing for intergenerational interaction and continuity, and postulates that they constructed a generational identity through the metaphor of a broken family. Authors belonging to the Generation of 1980 selfidentified as abandoned or orphaned children seeking to reconstruct a national artistic lineage severed during the regime (40). Whereas Pinochet represented his position as chief-ofstate through a familial metaphor in which he named himself the father of the nation, young 
subversive writers placed themselves outside this patriarchal familial model and declared their status as huachos or orphans as defined by their lack of a father figure. Cánovas shows the military's attempt to pull intellectual communities apart produced a rupture among artists who refused to participate in the symbolic national family Pinochet proposed: "Es una gesta relatada desde el resentimiento y la nostalgia hacia la figura del padre, y desde el rencor hacia los falsos ídolos que la sustituyeron." (41). Cánovas goes on to delineate a converse reaction of women writers in this literary "family," illustrating that their narratives reconfigure the traditional procreative role the regime assigned them: women writers, he argues, stressed their integral biological capacity to procreate, both in a familiar and literary sense. Women writers tended to focus on strengthening symbolic family ties, rather than emphasize ruptured family structures as did their male counterparts:

Paradójicamente, desde este espacio existencial de huerfanía primigenia surge una imagen renacida de la mujer, desde su papel de creadora. Serán portadoras de un linaje que gira en torno a la mujer (es el rito del legado materno, que genera la utopía de un nuevo comienzo), y de una actividad creativa ligada al razonamiento y a la escritura, que les permita recomponer la memoria familiar de la estirpe. (43)

"1954" exemplifies Cánovas's description: the story shows the figurative "births" of a female artist into a family of women writers and of a narrative text, the short story "1954" itself, a product of Basualto's connection to Mistral.

This reading of "1954" as an example of a female literary genealogy, however, begs for a more profound explanation of the social significance surrounding an orphaned status in Chile. The story itself invites this clarification: Basualto includes in one strategic moment in the narration the Chilean term for orphan-huaso-when the girls at the school berate the protagonist's father during his weekly retrieval of his daughter. In Chile, this derogatory term and its more common derivative, huacho, designate the absence of a man's father, whether the paternal figure is deceased or just does not recognize his son as his own. To be called a huacho signifies a man's lack of culture and his economic destitution, poor manners, and mixed race. A huacho is an orphan even though, in the standard representation, his mother is present and claims him. Chilean anthropologist and writer Sonia Montecino argues that the concept of the huacho is the cornerstone of Chilean national identity because it is the only family model that recognizes Chile's cultural amalgamation of Spanish and indigenous origins. Further, she highlights historical reasons making the absent father a crucial figure in the national imagination, beginning during the conquest when a massive union between transient Spanish men and indigenous women took place, and then later during the northern mining boom, when men worked in isolation from women, and finally in the years of the regime, when a significant rupture of the nuclear family occurred again due to disappearance and exile. Using this model to represent the nation through a familial metaphor limits the role of the symbolic Chilean woman to that of a single mother and procreator since there is no female equivalent to the huacho.

In "1954" Basualto ironically recasts women's traditional position within this archetypal Chilean family. Her reconfiguration augments the role of mothers in the constructive progression of national history and of Chilean identity. The author chooses to make Mistral central to the narration and underscores her status as a single mother of folds of young figurative Chilean "orphans," some of them like the protagonist, seeking out figures on which to mold their identity as writers. Further recalling this symbolic Chilean family, so like the budding author, Basualto equates 
the girl's particular search for origins with that of the huacho, who needs to fill the void created by the lack of a parental figure before becoming a legitimate member of society. The choice to make Mistral rather than another Chilean woman writer the surrogate mother of the young writerin-the-making facilitates the girl's easy adoption of a maternal substitute. Indeed, a large part of Mistral's work and self-image has to do with her problematic relationship with the maternal role, which she was able to fulfill only imaginatively through her verse and public image. Mistral's need to mother is met by the protagonist's search for a surrogate parent who recognizes her need to write, unlike the parental stand-in Pinochet, whom she will presumably reject in her adult life. Like Mistral, the young girl's need to produce and consume literature, which she uses to create a family, helps her cope with her own process of grieving the loss of her biological mother. This situation recalls the healing function of literature during the regime, much of which denounced the human rights abuses erased from the military's official history and therefore providing an important emotional outlet for Chileans affected by military violence.

Basualto manipulates another recognizable image of maternity to demonstrate the desirability of the alternative family unit she proposes in the story. Mixing Catholic imagery with the poet's ambiguous self-identity as a feminist and as the symbolic mother of all Chileans, the author portrays Mistral as if she were a lesser, yet legitimate version of the Virgin Mother. Instead of depicting her with a holy baby boy who will save humanity, Basualto has a young woman artist accompany the sacred woman as if she were her child. The description of Mistral's visit to the school and her brief contact with the protagonist highlights the comparison between Mistral and the Virgin while demonstrating the profound spiritual union between her and all Chilean children, particularly the protagonist:
[. . . ] la anciana se aleja del estrado y se dirige hace los cordones que la

separan de los niños. Alarga sus brazos y cientos de pequeñas manos tratan de tocarla. Alarga sus ojos y se detiene en una niñita de la fila de atrás. La sonrisa de la maestra inunda el rostro de la pequeña haciéndola enrojecer, mientras crece y crece y le dan ganas de salir volando. El corazón bate vertiginosamente $\mathrm{y}$ los ojos resplandecen bajo el sol rotundo ahora. De pronto ha desaparecido el cansancio y la mañana se vuelve perfecta. (60-1)

The image of the children as they reach for Mistral replicates the apparition not of a literary figure, but of a magical holy presence. Even nature seems to recognize Mistral's transformational capacity and contributes to her representation as a divine entity: the sun appears adorning her with a brilliant light that forms a makeshift halo, which then envelops the woman and "her" children. In linking the writer-to-be to Jesus by characterizing her as a person who is misunderstood by those who surround her, Basualto suggests that the young woman could potentially make an extraordinary contribution as a writer. In this manner Basualto hints at the crucial public importance of women writers, whom the Catholic Church and the Pinochet government authorized only in their reproductive roles as mothers, but not as cultural producers. Through her selection of Mistral as the model for the young writer, Basualto complicates a facile delineation of women's social roles since Mistral's own poetic oeuvre intertwines contradictory desires both to uphold and to challenge traditional gender roles. In many regards this is a similar tactic to the one Basualto employs in her own work, in which a seeming conformity to gender norms actually constitutes a subversion. "1954" suggests that women should be creators and push gender boundaries. Contrary to Pinochet's men and 
the nuns at the school, who consider writing a sullied and demonic activity, particularly for women, Basualto illustrates the moving power of women who pen their own stories and those of the nation.

In depicting these female protagonists as they attempt to create, Basualto's La mujer de yeso shows readers the reality of Chilean women writers in the 1980s who, despite military censorship and the attempted patriarchal reconfiguration of the nation, continually asserted their right to tell their own stories. Yet the aesthetic of silence and censorship, as Basualto shows us, links not only the 80s Generation writers, but many generations of women who have used literature to challenge their repression. This strategic and aesthetic implementation of military strategies to erode the regime's attempt to control each aspect of Chilean life added to the satchel of tools literary artists collected at this time.

\section{CONCLUSION}

My analyses of these two short stories demonstrate Basualto's extraordinary fusion of literary technique and political content, which allowed her to undermine not only the military, but also a wide range of factors that have attempted to subjugate women within the political, literary, educative, and familial structures. The fact that authors like Basualto created cunning strategies, such as the inauthentic acceptance of female silence, to maneuver within censorship should not be interpreted as a glorification of the aggressive circumstances precipitating her project. Rather, along with Basualto and others from her generation, I have attempted to expose the corrupt and antiquated premises of sociopolitical systems that garner power by silencing, erasing, and disenfranchising certain groups due not only to gender, but also to a wide range of factors of differentiation, such as race, class and sexual preference, that continue to provoke cultural producers to use the pen as a strategic armament.

\section{REFERENCIAS BIBLIOGRÁFICAS}

Basualto, Alejandra. La mujer de yeso. Ediciones Documentas, 1988.

---. Personal interview. 16 Jan 2004.

Bataille, George. El erotismo. Trans. Antoni Vicens and Mary Paule Sarazin. $5^{\text {th }}$ ed.

Les Édicions Minuit, 1957.

Bloom, Herold. The Anxiety of Influence: $A$ Theory of Poetry. Oxford UP, 1973.

Bourdieu, Pierre. The Rules of Art: Genesis and Structure of the Literary Field. Trans.

Susan Emanuel. Stanford UP, 1996.

Brito, Eugenia. Campos minados (literatura post-golpe en Chile). Editorial Cuarto

Propio, 1990.

Cánovas, Rodrigo. Novela chilena, nuevas generaciones: el abordaje del huérfano. Ediciones Universidad Católica de Chile, 1997.

Castillo, Debra A. Talking Back: Toward a Latin American Feminist Criticism. Cornell UP, 1992.

Constable, Pamela and Arturo Valenzuela. A Nation of Enemies: Chile Under Pinochet. W.W. Norton and Company, 1991.

Cuneo, Ana María. "La poesía de Alejandra Basualto: un viaje de regreso." Revista Chilena de Literatura, no. 24, 1984, pp. 119-24.

Epple, Juan Armando. "De piel a piel: El erotismo como escritura en la nueva narrativa femenina de Chile." Revista Iberoamericana, no. 65, vol. 187, 1999, pp. 383-94.

Espinosa, Patricia. "Narrativa chilena hoy." Nueva narrativa chilena, Edited by Carlos Oliváres. LOM Ediciones, 1997, pp. 65-74. 
La hinteligencia militar, Edited by Sergio Pesutic. Prensa Oxímoro, 1986.

Ludmer, Josefina. "Tretas del débil." La sartén por el mango, encuentro de escritoras

Latinoamericanas, Edited by Patricia Elena González and Eliana Ortega. Ediciones Huracán, 1984, pp. 47-54.

Millares, Selena and Alberto Madrid. "Última narrativa chilena: la escritura del desencanto." Cuadernos Hispanoamericanos, vol. 482, no. 83, 1990, pp. 113-22.

Montesino, Sonia. Madres y huachos: alegorías del mestizaje chileno. Editorial Sudamericana, 1996.

Osses, Mario. "Nosotros, los finiseculares." Cuadernos Hispanoamericanos, vol. 482, no. 83, 1990, pp. 137-147.

Richard, Nelly. Residuos y metáforas (Ensayos de crítica cultural sobre el Chile de la transición). $2^{\text {nd }}$ edition. Editorial Cuarto Propio, 2001.

Sommer, Doris. Proceed with Caution, When Engaged by Minority Writing in the Americas. Harvard UP, 1999.

Tisnado, Carmen. "Do Lesbian Characters Make Lesbian Stories? The Representation

of Lesbianism in Four South-American Short Stories." Desde aceras opuestas:

Literatura/cultura gay y lesbiana en Latinoamérica. Edited by Dieter Ingenschay. Iberoamericana and Vervuert, 2002, pp. 267-81.
Valenzuela, María Elena. La mujer en el Chile militar: todas íbamos a ser reinas. Ediciones Chile y América, 1987.

Zurita, Raúl. Literatura, lenguaje y sociedad (1973-1983). Ceneca, 1983. 